\title{
Evaluation of the quality characteristics of protein cubes supplemented with moringa leaf (Moringa oleifera Lam.) and green tea powders
}

\author{
Chae-Wan Baek, Jeung-Hee Lee* \\ Department of Food and Nutrition, Daegu University, Gyeongsan 38453, Korea
}

\begin{abstract}
The biological activities of moringa leaf and green tea powders were compared, and the quality characteristics of protein cubes supplemented with these powders $(5 \%$ and $7.5 \%$, respectively) were evaluated. The green tea powder had higher chlorophyll, essential fatty acid, total polyphenol (TPC), and flavonoid (TFC) contents than the moringa leaf powder. The green tea powder had higher levels of 2,2-diphenyl-1-picrylhydrazyl radical scavenging capacity (DPPH RSC), Trolox equivalent antioxidant capacity (TEAC), and ferric reducing antioxidant power (FRAP) than the moringa leaf powder, indicating higher antioxidant activity. The green tea powder inhibited the nitric oxide production to a greater extent than the moringa leaf powder. The protein cubes that were supplemented with either the moringa leaf or green tea powders had smaller volumes and were harder, chewier, and more easily fractured than the control protein cubes. The protein cubes supplemented with green tea powder had higher TPC and TFC, exhibited higher antioxidant activity $(\mathbf{p}<\mathbf{0 . 0 5})$, and had better sensory properties in terms of aroma, taste, and texture than the protein cubes supplemented with moringa leaf powder; however, the differences were not significant( $p>0.05)$. The results of the present study indicate that green tea is a more suitable health-oriented functional additive than moringa leaf in the development of high-protein and nutrient-rich bakery products with high consumer acceptability as well as antioxidant and anti-inflammatory properties.
\end{abstract}

Key words : antioxidant, green tea, Moringa oleifera, protein cube, quality characteristics

\section{Introduction}

Moringa (Moringa oleifera Lam.) is a plant that has recently garnered attention. Moringa leaves are rich in proteins with essential amino acids (leucine, lysine, and phenylalanine) (Moyo et al., 2011), and contain flavonoids, such as quercetin and kaempferol glycosides, which have antioxidant properties (Rodríguez-Pérez et al., 2015; Siddhuraju and Becker, 2003). Moringa leaf extracts have been reported to reduce the levels of tumor necrosis factor (TNF)- $\alpha$ and interleukin (IL)-6, thereby acting as potent anti-inflammatory agents. Additionally, these extracts have a retardation effect in diabetic nephropathy (Omodanisi et al., 2017).
Green tea (Camellia sinensis), a healthy ingredient contains high amounts of bioactive polyphenols such as falvan-3-ols (catechins), flavones, and flavonols (Rha et al., 2019). Catechins include epigallocatechin gallate (EGCG), epicatechin gallate (ECG), gallocatechin (GC), and epigallocatechin (EGC). Flavonols and flavones include myricetin, quercetin, apigenin, and kaempferol, which are mainly found in the form of glycosides (Stewart et al., 2005). Green tea polyphenolic compounds have anti- inflammatory, anticancer, and antioxidant properties (Rha et al., 2019).

The contemporary lifestyle and dietary patterns have increased the incidence of various diseases in adults; however, as people live longer, the desire for improved health and

\footnotetext{
*Corresponding author. E-mail : jeunghlee@daegu.ac.kr, Phone : +82-53-850-6836, Fax : +82-53-850-6839

Received 06 April 2021; Revised 14 July 2021; Accepted 14 July 2021.

Copyright (c) The Korean Society of Food Preservation.

This is an Open Access article distributed under the terms of the Creative Commons Attribution Non-Commercial License (http://creativecommons.org/licenses/by-nc/4.0) which permits unrestricted non-commercial use, distribution, and reproduction in any medium, provided the original work is properly cited.
} 
disease prevention has increased. Nowadays, people tend to use protein supplements in addition to exercising to become fitter. Adequate protein intake during exercise enhances muscle strength and hypertrophy development (Cribb and Hayes, 2006), leading to an increased demand for proteinenriched products (Lim et al., 2016; Park et al., 2020). Recently, easy-to-consume products such as nutrient bars have been increasingly introduced in the market; however, the development of protein-rich nutrient products has been insufficient, and commercially available products have received negative evaluations for taste and mouthfeel, owing to their characteristic dry and crumbling texture (Park et al., 2020).

Green tea leaf has been the highest contributor in the tea market, and there is a growing demand for green tea powders for home and business-to-business (B2B) use. Moringa leaves are also gaining popularity and considered as medicinal plants that benefit health (AT FIS, 2019). Studies are being conducted to investigate the processing quality parameters for the use of moringa leaves and green tea in food products. The rheological, nutritional, textural, organoleptic, and antioxidant effects of moringa leaves on bakery products (i.e., macarons and, cookies) have been investigated (Baek and Lee, 2020; Dachana et al., 2010). The antioxidant properties and quality characteristics (physical, nutraceutical, and sensory properties) of bakery products (cookies, macarons, or rice sponge cakes) supplemented with green tea have also been investigated (Ahmad et al., 2015; Baek and Lee, 2020; Lee and Hwang, 2016). However, comparative studies on the potential use of moringa leaves and green tea as functional additives in the development of protein supplements are still limited.

In this study, the chemical composition (chlorophyll and fatty acids) and biological activities (antioxidant activity and inhibitory effect of nitric oxide production) of moringa leaf and green tea powders were compared. Furthermore, portable and easily consumable protein cubes were prepared to determine whether moringa leaves and green tea powders could be used as food additives in protein supplements, and to evaluate their quality, sensory properties, and antioxidant properties.

\section{Materials and methods}

\section{Materials}

Moringa leaves (Grenera nutrients Pvt., Ltd., Erode,
Tamil Nadu, India) and green tea (Nokchawon Co., Ltd., Seoul, Korea) were purchased in powdered form. Almond powder (Woosin Food Co., Ltd., Incheon, Korea), soft wheat flour (CJ Cheiljedang Co., Ltd., Incheon, Korea), protein powder (Marquez Brothers International, Inc., San Jose, CA, USA), milk and butter (Seoul Milk Co., Ltd., Seoul, Korea), cream cheese (Fromageries Bel, Vendome, France), and sugar powder (Kkomida Co., Ltd., Incheon, Korea) were purchased from the market. Folin \& Ciocalteu's phenol reagent, gallic acid, quercetin, DPPH, TPTZ, ABTS, and lipopolysaccharides (LPS) were purchased from SigmaAldrich Co. Ltd. (St. Louis, MO, USA). The sulfanilamide solution and $\mathrm{N}$-1- naphthylethylenediamine dihydrochloride (NED) solution were purchased from Promega (Madison, WI, USA), and Dulbecco's modified Eagle medium (DMEM) was purchased from HyClone (Logan, UT, USA). Mouse-derived macrophage RAW 264.7 cells were obtained from the Korea Cell Line Bank (Seoul, Korea).

\section{Preparation of protein cubes}

The ingredients of the protein cubes preparation were almond powder $(18 \%, \mathrm{w} / \mathrm{w})$, soft wheat flour $(21 \%)$, protein powder $(12 \%)$, milk $(9 \%)$, butter $(13 \%)$, cream cheese $(13 \%)$, and sugar powder (13\%). In a preliminary study, protein cubes were prepared by substituting 3\%, 5\%, 7.5\%, and $10 \%$ of moringa leaf or green tea powder for soft wheat flour. The 5\% and 7.5\% substitution levels had good sensory properties and were selected for the present study. All ingredients were mixed to make a dough, which was spread in a square frame $(14 \mathrm{~cm} \times 8 \mathrm{~cm} \times 1.5 \mathrm{~cm})$ and covered with a plastic wrap. After chilling the dough in a refrigerator at $4^{\circ} \mathrm{C}$ for $90 \mathrm{~min}$, it was cut into $2 \mathrm{~cm} \times 2 \mathrm{~cm} \times 1.5 \mathrm{~cm}$ cubes, and baked in an oven at $140^{\circ} \mathrm{C}$ top heat and $150^{\circ} \mathrm{C}$ bottom heat for $35 \mathrm{~min}$. The baked protein cubes were cooled to room temperature $\left(27 \pm 2^{\circ} \mathrm{C}\right)$.

\section{Analysis of the chlorophyll content}

Acetone $(85 \%, 26 \mathrm{~mL})$ was added to the powder $(500$ $\mathrm{mg}$ ) and sonicated for $20 \mathrm{~min}$ (JAC-2010; KODO Technical Research Co. Ltd., Hwaseog, Korea), followed by centrifugation $(1,763 \times g, 10 \mathrm{~min})$ to separate the supernatant. The $85 \%$ acetone was added to the residue for repeated extraction until the pigment was completely removed. All collected supernatants were combined and adjusted to a total volume 
of $200 \mathrm{~mL}$. Then, $25 \mathrm{~mL}$ was transferred to a separatory funnel and mixed with ether $(50 \mathrm{~mL})$ and distilled water $(25$ $\mathrm{mL}$ ), after which the ether layer was collected twice. After adding sodium sulfate to remove moisture, the supernatant was adjusted to a total volume of $100 \mathrm{~mL}$, from which 10 $\mathrm{mL}$ was concentrated with $\mathrm{N}_{2}$ and re-dissolved in ether (3 $\mathrm{mL}$ ). The absorbance was measured at $660 \mathrm{~nm}$ and $642 \mathrm{~nm}$, and the total chlorophyll, chlorophyll $\mathrm{a}$, and chlorophyll $\mathrm{b}$ contents of the powders $(\mathrm{mg} / 100 \mathrm{~g})$ were calculated using the method of Kripanand et al. (2015).

\section{Analysis of total phenolics and flavonoid contents}

The powder or crushed protein cubes were mixed in $80 \%$ ethanol $(50 \mathrm{~mL})$ and extracted in a shaking water bath at $55^{\circ} \mathrm{C}$ and 125 rpm (LSB-045S; Daihan Labtech Co., Namyangju, Korea) for $2 \mathrm{~h}$, followed by sonication and subsequent centrifugation $(1,763 \times g, 10 \mathrm{~min})$ for $1 \mathrm{~h}$. The supernatant was collected, and a sodium sulfate column was used to remove moisture. The obtained extract was concentrated using a rotary evaporator (SB-1200; EYELA, Tokyo, Japan) and dried with $\mathrm{N}_{2}$.

The total phenolics contents (TPC) was measured using the Folin-Denis phenol method (Chang et al., 2020). In a test tube, $80 \%$ diluted ethanol extract $(0.5 \mathrm{~mL})$, FolinCiocalteu's phenol reagent $(0.5 \mathrm{~mL})$, and distilled water $(4.5$ $\mathrm{mL}$ ) were mixed and reacted for $3 \mathrm{~min}$. Then, $1 \mathrm{~N} \mathrm{Na}_{2} \mathrm{CO}_{3}$ $(1 \mathrm{~mL})$ was added to the reaction mixture and incubated in the dark for $1 \mathrm{~h}$; the absorbance was measured at $725 \mathrm{~nm}$ using a microplate reader (Multiskan GO; Thermo Scientific, Waltham, MA, USA). A calibration curve was obtained using gallic acid, and TPC was calculated and expressed as mg gallic acid equivalent (GAE)/g powder (or protein cube).

The total flavonoid contents (TFC) was measured using the method described by Chang et al. (2020). In a test tube, a diluted solution of $80 \%$ ethanol extract $(1 \mathrm{~mL})$ was mixed with distilled water $(4 \mathrm{~mL})$ and allowed to react for $5 \mathrm{~min}$; then a $5 \% \mathrm{NaNO}_{2}$ solution $(0.3 \mathrm{~mL})$ and $10 \% \mathrm{AlCl}_{3}$ solution $(0.3 \mathrm{~mL})$ were added and reacted for $6 \mathrm{~min}$. Then, $1 \mathrm{M}$ $\mathrm{NaOH}(2 \mathrm{~mL})$ and distilled water $(2.4 \mathrm{~mL})$ were added, and the absorbance was measured at $510 \mathrm{~nm}$ using a microplate reader. A standard curve was obtained using a quercetin solution, and the TFC was expressed as mg quercetin equivalent $(\mathrm{QE}) / \mathrm{g}$ of powder (or protein cube).

\section{Determination of DPPH free radical scavenging capacity (RSC)}

The $80 \%$ diluted ethanol extract $(0.2 \mathrm{~mL})$, ethanol $(1.8$ $\mathrm{mL})$, and $0.15 \mathrm{mM}$ DPPH solution $(2.5 \mathrm{~mL})$ were mixed in a test tube, and reacted in the dark for $30 \mathrm{~min}$. The absorbance (Abs) was measured at $517 \mathrm{~nm}$ using a microplate reader. The DPPH RSC (\%) of the powder (or protein cube) was calculated using the following equation:

DPPH Free radical scavenging activity $(\%)=$

$$
\frac{\mathrm{Abs}_{\text {blank }}-\mathrm{Abs}_{\text {sample }}}{\mathrm{Abs}_{\text {blank }}} \times 100
$$

\section{Determination of ferric reducing antioxidant power (FRAP)}

A FRAP reagent was prepared by mixing $250 \mathrm{~mL}$ of acetate buffer ( $300 \mathrm{mM}, \mathrm{pH} 3.6), 10 \mathrm{mM}$ TPTZ solution (25 $\mathrm{mL}$ ), and $20 \mathrm{mM} \mathrm{FeCl} 3 \cdot 6 \mathrm{H}_{2} \mathrm{O}$ solution $(25 \mathrm{~mL})$. In a test tube, the $80 \%$ diluted ethanol extract $(150 \mu \mathrm{L})$ and a FRAP reagent $(4.5 \mathrm{~mL})$ were mixed, and incubated at $37^{\circ} \mathrm{C}$ for 4 min in a water bath (Dailhan Labtech Co., Namyangju, Korea). The absorbance was measured at $593 \mathrm{~nm}$ using a microplate reader. Ascorbic acid was used to prepare a standard curve. FRAP was calculated and expressed as mg ascorbic acid equivalent (AAE)/g of powder (or protein cube).

\section{Determination of trolox equivalent antioxidant capacities (TEACs)}

ABTS radicals were generated by mixing $7 \mathrm{mM}$ ABTS and $2.45 \mathrm{mM}$ potassium persulfate $(1: 0.5, \mathrm{v} / \mathrm{v})$ (Re et al., 1999) at room temperature in the dark for $12-16 \mathrm{~h}$ and diluted with ethanol until the absorbance at $734 \mathrm{~nm}$ was $0.7 \pm 0.02$. The $80 \%$ diluted ethanol extract $(250 \mu \mathrm{L})$ was reacted with the ABTS radical solution $(5 \mathrm{~mL})$ in a test tube for $6 \mathrm{~min}$, and the absorbance at $734 \mathrm{~nm}$ was measured. A standard curve was obtained using Trolox, and the TEACs were calculated and expressed as mg Trolox equivalent (TE)/g of powder.

\section{Analysis of inhibitory activity on nitric oxide (NO) production}

Mouse-derived macrophage RAW 264.7 cells were cultured in DMEM containing 10\% fetal bovine serum (FBS), 100 
$\mathrm{U} / \mathrm{mL}$ penicillin, and $100 \mu \mathrm{g} / \mathrm{mL}$ streptomycin under $5 \%$ $\mathrm{CO}_{2}$ and $95 \%$ humidity at $37^{\circ} \mathrm{C}$ in an incubator. The RAW 264.7 cells were seeded and cultured in a 24 -well plate at $1 \times 10^{5}$ cells $/ \mathrm{mL} /$ well for $24 \mathrm{~h}$. After removing the medium, fresh DMEM (1\% FBS, $100 \mathrm{U} / \mathrm{mL}$ penicillin and 100 $\mu \mathrm{g} / \mathrm{mL}$ streptomycin) and either $100 \mathrm{ng} / \mathrm{mL}$ phosphatebuffered saline (PBS) (negative control), $100 \mathrm{ng} / \mathrm{mL}$ LPS (LPS group), or $100 \mathrm{ng} / \mathrm{mL}$ LPS $+20 \mathrm{mg} / \mathrm{mL}$ of $80 \%$ ethanol extract (powder groups) was added. After culturing $96 \mathrm{~h}$, each supernatant $(50 \mu \mathrm{L})$ was taken and sulfanilamide solution $(50 \mu \mathrm{L})$ was added, and the mixture was left in the dark for 5-10 min. Then, a NED solution (50 $\mu \mathrm{L})$ was added to the mixture and reacted for another 5-10 $\mathrm{min}$ before measuring the absorbance at $535 \mathrm{~nm}$. Sodium nitrite solutions were prepared to obtain a standard curve, and the level of NO production was calculated. The NO production rates in the powder groups are represented as percentages based on NO production in the LPS group.

\section{Analysis of fatty acid composition}

The powder $(2 \mathrm{~g})$ and crushed protein cubes $(2 \mathrm{~g})$ were extracted with $n$-hexane $(50 \mathrm{~mL})$ for $30 \mathrm{~min}$ and a Folch solution $(50 \mathrm{~mL})$ for $1 \mathrm{~h}$, respectively, in a shaking water bath $\left(55^{\circ} \mathrm{C}, 135 \mathrm{rpm}\right)$. After centrifugation $(740 \times \mathrm{g}, 5 \mathrm{~min})$, the upper layer was concentrated with $\mathrm{N}_{2}$, and crude lipids were obtained from the powder and protein cubes. Crude lipids $(50 \mathrm{mg})$, triundecanoin $(1 \mathrm{~mL}, 5 \mathrm{mg} / \mathrm{mL}$ isooctane), and a $0.5 \mathrm{~N}$ methanolic $\mathrm{NaOH}$ solution $(1.5 \mathrm{~mL})$ were mixed in a test tube and saponified at $85^{\circ} \mathrm{C}$ for $10 \mathrm{~min}$. After cooling, $\mathrm{BF}_{3}$-methanol $(2 \mathrm{~mL})$ was added, and the mixture reacted at $85^{\circ} \mathrm{C}$ for $10 \mathrm{~min}$ for methylation. Isooctane $(2 \mathrm{~mL})$ was mixed for $1 \mathrm{~min}$, and centrifuged (1,224 $\times g, 5 \mathrm{~min})$, and the upper layer was collected. Fatty acid compositions were analyzed using a gas chromatograph (GC-2010 Plus; Shimadzu Corp., Kyoto, Japan) equipped with a flame ionization detector and an $\mathrm{SP}^{\mathrm{TM}}-2560$ column (biscyanopropyl polysiloxane, $100 \mathrm{~m} \times 0.25 \mathrm{~nm} \times 0.2 \mu \mathrm{m}$ film thickness; Supelco Co., St. Louis, MO, USA) according to the modified method of Gan et al. (2012).

\section{Analysis of texture profile and volume of protein cubes}

The texture profile analysis (TPA) of the protein cubes was performed using a Rheometer (Compac-100; Sun
Scientific, Tokyo, Japan) equipped with a $10-\mathrm{kg}$ load cell and a cylindrical probe with a diameter of $4 \mathrm{~mm}$ (No. 4) at a table speed of $120 \mathrm{~mm} / \mathrm{min}$ and $30 \%$ of the entrance distance. TPA was performed in triplicate to determine chewiness, fracturability, and hardness. The volume of the protein cubes was quantified by measuring the volume of a granular material (used with millet) displaced by a protein cube in a 4-L plastic container according to the modified method of Baek and Lee (2020).

\section{Sensory evaluation of protein cubes}

The sensory properties of the protein cube were evaluated using a panel comprising 42 students. The panelists were informed about each of the evaluated items and trained before sensory evaluation was performed (IRB Approval No. 1040621-201909-HR-019-08). The sensory attribute intensity of the protein cubes was evaluated with a greenish color, grassy smell, taste, and hardness. Sensory acceptability was assessed based on appearance, color, aroma, taste, texture, and overall acceptability. A 7-point hedonic scale (1-weak or dislike extremely; 4-normal or neither dislike nor like; 7-strong or like extremely) was used for sensory evaluation.

\section{Statistical analysis}

Analysis of variance (ANOVA) was performed using the Statistical Analysis System 9.2 (SAS Institute, Inc., Cary, NC, USA). The experimental results were expressed as mean \pm standard deviation (SD). For NO production, the results were expressed as the mean \pm standard error of the mean (SEM), and GraphPad Prism 5 (San Diego, CA, USA) was used to perform one-way ANOVA. The statistical differences of the means were determined using Student's t-test, Duncan's multiple range test, or Dunnett's test at $\mathrm{p}<0.05$.

\section{Results and discussion}

\section{Chlorophyll content of the moringa leaf and green tea powders}

The total chlorophyll contents were 1.3-fold higher in the green tea powder $(269 \mathrm{mg} / 100 \mathrm{~g})$ than in the moringa leaf powder $(205 \mathrm{mg} / 100 \mathrm{~g})$. Chlorophyll $\mathrm{a}$ and $\mathrm{b}$ contents were 1.34-fold and 1.24-fold higher, respectively, in green tea powder than in moringa leaf powder (Table 1). Previous 
Table 1. Chlorophyll, total phenolics and flavonoid contents, and antioxidant activities

\begin{tabular}{|c|c|c|c|c|c|}
\hline Powder & \multicolumn{3}{|c|}{ Moringa leaf } & \multicolumn{2}{|c|}{ Green tea } \\
\hline \multicolumn{6}{|l|}{ Chlorophyll contents } \\
\hline Total chlorophyll (mg/100 g) & \multicolumn{3}{|c|}{$205.08 \pm 11.02^{1)}$} & \multicolumn{2}{|c|}{$268.89 \pm 18.97^{* 2)}$} \\
\hline Chlorophyll a (mg/100 g) & \multicolumn{3}{|c|}{$150.13 \pm 8.32$} & \multicolumn{2}{|c|}{$200.92 \pm 14.18^{*}$} \\
\hline Chlorophyll b (mg/100 g) & \multicolumn{3}{|c|}{$55.08 \pm 2.00$} & \multicolumn{2}{|c|}{$68.13 \pm 6.04^{*}$} \\
\hline $\mathrm{TPC}^{3)}\left(\mathrm{mg} \mathrm{GAE}^{8)} / \mathrm{g}\right)$ & \multicolumn{3}{|c|}{$16.95 \pm 0.02$} & \multicolumn{2}{|c|}{$130.11 \pm 5.75^{*}$} \\
\hline $\mathrm{TFC}^{4)}\left(\mathrm{mg} \mathrm{QE}^{8)} / \mathrm{g}\right)$ & \multicolumn{3}{|c|}{$30.31 \pm 0.38$} & \multicolumn{2}{|c|}{$84.58 \pm 0.59^{*}$} \\
\hline DPPH $\mathrm{RSC}^{5)}(\%)$ & \multicolumn{3}{|c|}{$9.75 \pm 0.00$} & \multicolumn{2}{|c|}{$58.48 \pm 0.00^{*}$} \\
\hline $\mathrm{FRAP}^{6)}\left(\mathrm{mg} \mathrm{AAE}^{8)} / \mathrm{g}\right)$ & \multicolumn{3}{|c|}{$19.99 \pm 0.37$} & \multicolumn{2}{|c|}{$251.48 \pm 1.47^{*}$} \\
\hline $\mathrm{TEAC}^{7)}\left(\mathrm{mg} \mathrm{TE} \mathrm{TE}^{8)} / \mathrm{g}\right)$ & \multicolumn{3}{|c|}{$34.46 \pm 0.20$} & \multicolumn{2}{|c|}{$553.47 \pm 13.72^{*}$} \\
\hline \multirow{2}{*}{ Protein cube } & \multirow{2}{*}{ Control } & \multicolumn{2}{|c|}{ Moringa leaf } & \multicolumn{2}{|c|}{ Green tea } \\
\hline & & $5 \%$ & $7.5 \%$ & $5 \%$ & $7.5 \%$ \\
\hline TPC (mg GAE/g) & $0.27 \pm 0.01^{\mathrm{d} 9)}$ & $0.89 \pm 0.09^{c}$ & $1.30 \pm 0.57^{\mathrm{c}}$ & $2.37 \pm 0.57^{b}$ & $3.19 \pm 0.21^{\mathrm{a}}$ \\
\hline TFC (mg QE/g) & $1.13 \pm 0.06^{\mathrm{d}}$ & $1.16 \pm 0.15^{\mathrm{d}}$ & $1.56 \pm 0.10^{\mathrm{c}}$ & $3.89 \pm 0.17^{b}$ & $4.95 \pm 0.24^{\mathrm{a}}$ \\
\hline DPPH RSC (\%) & $2.24 \pm 0.58^{\mathrm{c}}$ & $63.18 \pm 2.7^{b}$ & $79.28 \pm 0.22^{\mathrm{a}}$ & $79.85 \pm 0.29^{\mathrm{a}}$ & $80.54 \pm 0.68^{\mathrm{a}}$ \\
\hline FRAP (mg AAE/g) & $0.06 \pm 0.02^{\mathrm{d}}$ & $0.13 \pm 0.03^{\mathrm{d}}$ & $0.57 \pm 0.11^{\mathrm{c}}$ & $2.90 \pm 0.34^{\mathrm{b}}$ & $4.52 \pm 0.41^{\mathrm{a}}$ \\
\hline
\end{tabular}

${ }^{1)}$ Each value is $\operatorname{mean} \pm \mathrm{SD}(\mathrm{n}=2)$.

${ }^{2)^{*}}$ Indicate a significant difference between moringa leaf and green tea powders by Student's t-test at $\mathrm{p}<0.05$.

${ }^{3)} \mathrm{TPC}$, total phenolic content.

${ }^{4)}$ TFC, total flavonoid content.

${ }^{5)} \mathrm{DPPH}$. free radical scavenging capacity.

${ }^{6}$ FRAP, ferric reducing antioxidant power.

${ }^{7)}$ TEAC, trolox equivalent antioxidant capacities

${ }^{8)} \mathrm{GAE}$, gallic acid equivalent; QE, quercetin equivalent; AAE, ascorbic acid equivalent; TE, trolox equivalent.

${ }^{9) a-d}$ Values with different superscripts within the same row are significantly different by Duncan's multiple range test at $\mathrm{p}<0.05$.

studies have reported that the total chlorophyll contents in green tea were $170-710 \mathrm{mg} / 100 \mathrm{~g}$, and the chlorophyll a and b contents were $71-401 \mathrm{mg} / 100 \mathrm{~g}$ and $93-309 \mathrm{mg} / 100 \mathrm{~g}$, respectively (Lee et al., 2010). The total chlorophyll contents in moringa leaves were reported as $232-532 \mathrm{mg} / 100 \mathrm{~g}$, while the chlorophyll $\mathrm{a}$ and $\mathrm{b}$ contents were $170-359 \mathrm{mg} / 100 \mathrm{~g}$ and 61-173 mg/100 g, respectively (Wasonowati et al., 2019). These reports indicated that the chlorophyll content of green tea and moringa leaves was wide and varied, and corroborate the results of the present study.

During cultivation, the chlorophyll content is influenced by weather conditions, such as temperature and humidity. Furthermore, as the effect of light on photosynthesis varies from region to region, there are regional differences in the chlorophyll content of plants (Lee et al., 2010; Wasonowati et al., 2019). In addition, the chlorophyll content may decrease as chlorophyll may undergo decomposition into pheophytin or pheophorbide owing to its sensitivity to temperature, $\mathrm{pH}, \mathrm{O}_{2}$, and light during storage; additionally, chlorophyll $\mathrm{a}$ is thermally less stable than chlorophyll $\mathrm{b}$ (Choe et al., 2001).

\section{Fatty acid composition of the moringa leaf and green tea powders}

The crude lipid content was 1.46-fold higher in the moringa leaf powder $(7.79 \%)$ than in the green tea powder (5.33\%) (Table 2). The major fatty acids in moringa leaves were $\alpha$-linolenic (28.53\%), palmitic (22.8\%), cis-vaccenic (9.18\%), linoleic (7.97\%), and lignoceric acids (7.16\%), while those in green tea were $\alpha$-linolenic $(40.55 \%)$, palmitic (25.54\%), linoleic $(16.50 \%)$, oleic $(7.27 \%)$, and stearic acids (3.32\%) (Table 2). Compared with moringa leaves, green tea had 1.42-fold, 2.07-fold, and 1.29-fold higher $\alpha$-linolenic acid, linoleic acid, and oleic acid contents, respectively. 
Table 2. Fatty acid composition of the moringa leaf and green tea powders

\begin{tabular}{lcc}
\hline & Moringa leaf & Green tea \\
\hline Crude lipids (\%) & $7.79 \pm 0.02^{\left.1)^{*} 2\right)}$ & $5.33 \pm 0.02$ \\
\hline Fatty acid (\% of total fatty acids) & & \\
Lauric acid (C12:0) & $0.42 \pm 0.02^{*}$ & $0.18 \pm 0.04$ \\
Myristic acid (C14:0) & $2.80 \pm 0.06^{*}$ & $0.81 \pm 0.01$ \\
Palmitic acid (C16:0) & $22.88 \pm 0.52$ & $25.54 \pm 0.33^{*}$ \\
Palmitoleic acid (C16:1) & $0.22 \pm 0.00$ & $0.42 \pm 0.01^{*}$ \\
Heptadecanoic acid (C17:0) & $0.42 \pm 0.01^{*}$ & $0.23 \pm 0.02$ \\
Heptadecenoic acid (C17:1) & $0.41 \pm 0.00^{\mathrm{NS}}$ & $0.32 \pm 0.25$ \\
Stearic acid (C18:0) & $4.69 \pm 0.11^{*}$ & $3.32 \pm 0.11$ \\
Oleic acid (C18:1n-9c) & $5.60 \pm 0.15$ & $7.27 \pm 0.15^{*}$ \\
Vaccenic acid (C18:1n-7c) & $9.18 \pm 0.29^{*}$ & $1.07 \pm 0.23$ \\
Linoleic acid (C18:2n-6c) & $7.97 \pm 2.05$ & $16.50 \pm 0.08^{*}$ \\
Arachidic acid (C20:0) & $1.88 \pm 0.02^{*}$ & $0.22 \pm 0.01$ \\
$\alpha$-Linolenic acid (C18:3n-3) & $28.53 \pm 0.63$ & $40.55 \pm 0.40^{*}$ \\
Eicosadienoic acid (C20:2) & $0.46 \pm 0.04^{*}$ & $0.15 \pm 0.17$ \\
Behenic acid (C22:0) & $3.06 \pm 0.01^{*}$ & $0.39 \pm 0.01$ \\
Erucic acid (C22:1n-9) & $2.20 \pm 0.08^{*}$ & $0.38 \pm 0.14$ \\
Tricosylic acid (C23:0) & $0.54 \pm 0.06^{*}$ & $0.24 \pm 0.01$ \\
Lignoceric acid (C24:0) & $7.16 \pm 0.03^{*}$ & $1.29 \pm 0.02$ \\
Nervonic acid (C24:1n9) & $0.48 \pm 0.1^{\mathrm{NS}}$ & $0.31 \pm 0.21$ \\
\hline$\sum$ SFA $^{3)}$ & $44.56 \pm 0.78^{*}$ & $32.60 \pm 0.43$ \\
$\sum$ USFA ${ }^{3}$ & $55.48 \pm 0.83$ & $67.59 \pm 0.51^{*}$ \\
\hline MUFA ${ }^{3)}$ & $18.28 \pm 0.57^{*}$ & $10.20 \pm 0.80$ \\
\hline P) & $37.19 \pm 1.38$ & $57.39 \pm 0.29^{*}$ \\
\hline
\end{tabular}

${ }^{1)}$ Each value is mean \pm SD $(n=3)$.

2)* Indicate a significant difference between moringa leaves and green tea by Student's t-test at $\mathrm{p}<0.05$. NS, not significantly different at $\mathrm{p}<0.05$.

${ }^{3)}$ SFA, saturated fatty acid; USFA, unsaturated fatty acid; MUFA, monounsaturated fatty acid; PUFA, polyunsaturated fatty acid.

Moyo et al. (2011) reported that the major fatty acids in moringa leaves are $\alpha$-linolenic (44.57\%), palmitic (11.79\%), linoleic $(7.44 \%)$, oleic $(3.96 \%)$, lignoceric $(2.91 \%)$, stearic (2.13\%), and cis-vaccenic acids (0.36\%). Anh et al. (2016) reported that the major fatty acids in green tea are $\alpha$ -linolenic (13.34-22.58\%), palmitic (15.3-32.41\%), linoleic (6.8-39.04\%), oleic (15.03-29.9\%), and stearic acids (7.27-
49.8\%). The major fatty acid compositions of moringa leaves and green tea in these reports are slightly different from those found in the present study, likely due to differences in leaf age, soil type, and weather conditions (Anh et al., 2016; Moyo et al., 2011).

Oleic acid (n-9) has been reported to lower the risk of cardiovascular disease by reducing the high-density lipoprotein/ low-density lipoprotein ratio (Terés et al., 2008). Essential fatty acids (EFAs), such as $\alpha$-linolenic acid (n-3) and linoleic acid (n-6), decrease insulin resistance and exhibit antibiotic- like activity. EFAs and their $\mathrm{n}-6$ chain $(\gamma$-linoleic acid and arachidonic acid) and n-3 long-chain metabolites (eicosapentaenoic acid and docosahexaenoic acid) have important secondary messenger activities, which reduce the production of proinflammatory eicosanoids and cytokines, leading to anti- inflammatory effects (Das, 2006). The intake of polyunsaturated fatty acids (PUFAs) with low n-6/n-3 ratios (1:1 and 5:1) in rats fed a high-fat diet was beneficial in reducing the risk of cardiovascular disease by promoting favorable lipid profiles as well as anti-inflammatory and anti-oxidative effects and by improving endothelial function; in contrast, the intake of PUFA with a high $n-6 / n-3$ ratio (20:1) had adverse effects in high-fat diet-fed mice (Yang et al., 2015). In the present study, the green tea and moringa leaf powders had lower n-6 (linoleic acid)/n-3 ( $\alpha$-linolenic acid) ratios of 2.43 and 3.48 , respectively. The green tea powder had higher PUFA content with a lower $n-6 / n-3$ ratio, lower SFA, and higher EFA content than moringa leaf powder.

\section{The TPC and TFC of moringa leaf and green tea powders}

The TPC of green tea $(130.11 \mathrm{mg}$ GAE/g) was 7.7 -fold higher than that of moringa leaf powder (16.95 mg GAE/g) $(\mathrm{p}<0.05)$. The TFC of green tea $(84.58 \mathrm{mg} \mathrm{QE} / \mathrm{g})$ was 2.8 -fold higher than that of moringa leaf powder $(30.31 \mathrm{mg}$ $\mathrm{QE} / \mathrm{g})(\mathrm{p}<0.05)$ (Table 1). In line with this, previous studies have reported that the TPC and TFC of green tea (71-122 $\mathrm{mg} \mathrm{GE} / \mathrm{g}$ or $136-231 \mathrm{mg} \mathrm{GAE} / \mathrm{g}$, and $27-61 \mathrm{mg} \mathrm{CEQ} / \mathrm{g}$, respectively) are higher than those of moringa leaves (36-45 $\mathrm{mg} \mathrm{GAE} / \mathrm{g}$ or $29-42 \mathrm{mg} \mathrm{GAE} / \mathrm{g}$, and $15-27 \mathrm{mg} \mathrm{QE} / \mathrm{g}$, respectively) (Chen and Ho, 2007; Nadiah et al., 2015; Siddhuraju and Becker, 2003; Sreelatha and Padma, 2009). Phenolics are the most widespread secondary metabolites 
of plants (Nadiah et al., 2015; Sreelatha and Padma, 2009). The major bioactive phenolic compounds in moringa leaves are flavonoids (quercetin and kaempferol derivatives), phenolic acids, and their derivatives (caffeoylquinic, feruloylquinic, and coumaroylquinic acids) (Rodríguez-Pérez et al., 2015). The contents of quercetin and kaempferol derivatives in moringa leaves vary from $6.34-27.49 \mathrm{mg} / \mathrm{g}$ to $1.75-6.27$ $\mathrm{mg} / \mathrm{g}$, depending on the agroclimatic origin (Siddhuraju and Becker, 2003). The major phenolic compounds in green tea are catechins, phenolic acids (gallic acid and 5-galloylquinic acid), flavonols (quercetin and kaempferol derivatives), and caffeoylquinic acid (Stewart et al., 2005). As the content of phenolic compounds in plants is used to evaluate antioxidant activity in natural products (Siddhuraju and Becker, 2003), in the present study, the antioxidant activity was evaluated after measuring the TPC and TFC of the green tea and moringa leaf powder.

\section{Antioxidant activity of the moringa leaf and green tea powders}

The antioxidant activity of the moringa leaf and green tea powders was assessed using DPPH RSC, FRAP, and TEAC (Table 1). DPPH RSC(\%) was 6-fold higher in green tea $(58.48 \%)$ than in moringa leaves extracts $(9.75 \%)(p<0.05)$. FRAP was 12.6-fold higher in green tea than in moringa leaves $(\mathrm{p}<0.05)$, while TEAC was 16.1-fold higher in green tea than in moringa leaves $(\mathrm{p}<0.05)$. The higher antioxidant

activity in green tea powder than in moringa leaf powder was likely because TPC and TFC were higher in green tea than in moringa leaves $(\mathrm{p}<0.05)$, as the phenolic compound and flavonoid contents were positively correlated with antioxidant activity.

The major phenolic compounds in moringa leaves, quercetin and kaempferol, are mostly found as glycoside derivatives (Rodríguez-Pérez et al., 2015; Siddhuraju and Becker, 2003). The most abundant phenolic compounds in green tea, catechins (flavan-3-ols), are found as flavonol alycones, which catechins account for $68 \%$ of the total antioxidant potential of green tea. Approximately $30 \%$ of the its total antioxidant activity of green tea is attributed to EGCG, the concentration of which is considerably high in green tea (Rha et al., 2019; Stewart et al., 2005). The significant contribution of flavan3-ols to antioxidant activity can be attributed to their specific molecular structure which lacks a carbonyl group at carbon 4 and a double bond between carbons 2-3 in the $\mathrm{C}$ ring, and possesses a galloyl moiety at carbon 3 in the $\mathrm{C}$ ring as well as hydroxylation in the B ring (Stewart et al., 2005). Therefore, the high antioxidant potential of green tea can be attributed to the high catechin (flavan-3-ols) contents, which exhibit higher antioxidant activity than flavonols (in the form of glycoside derivatives) in moringa leaves.

\section{Inhibitory effects of moringa leaf and green tea powders on NO production}

The anti-inflammatory effects of moringa leaf and green tea powder extracts were assessed based on their inhibitory activities on NO production in RAW 264.7 cells using LPS. NO is a potent inflammatory mediator produced from L-arginine by inducible nitric oxide synthase (iNOS), and excessive NO production can play a proinflammatory role in the induction of chronic inflammatory diseases (Chan et al., 1997; Santangelo et al., 2007). The NO production was significantly higher in the LPS group $(100 \%)$ than in the negative control $(2.2 \%)$. While the green tea extract significantly reduced NO production by $85.6 \%(\mathrm{p}<0.05)$, no significant inhibition of $\mathrm{NO}$ production was found in the moringa leaf extract $(\mathrm{p}>0.05)$, indicating that the inhibitory activity of green tea extract on NO production was higher than that of moringa leaf extract (Fig. 1).

Inflammation is a normal immune response of the body; however, its abnormal regulation leads to the release of high levels of inflammatory factors, inducing tissue damage and

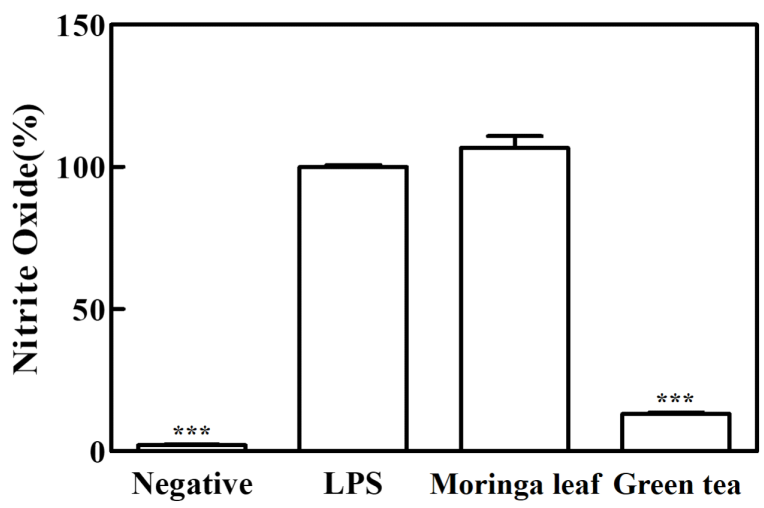

Fig. 1. The inhibitory effects of moringa leaf and green tea extracts on LPS-induced nitric oxide production in RAW 264.7 cells.

Treated with $20 \mathrm{mg} / \mathrm{mL}$ of moringa leaf or green tea extract. ${ }^{* * *}$ Statistical significance is based on the difference compared with LPS by Dunnett's test at $\mathrm{p}<0.001$. 
chronic inflammation (Santangelo et al., 2007). Phenolic compounds can modulate anti-inflammatory activities by inhibiting the inflammatory transcription factor, nuclear factor-B $(\mathrm{NF}-\kappa \mathrm{B})$, and the mitogen-activated protein kinase (MAPK) pathway. A variety of flavonoids downregulate NO production and iNOS gene expression in RAW 264.7 macrophages (Santangelo et al., 2007). The EGCG in green tea decreases NO production by reducing iNOS gene expression and inhibiting enzyme activity (Chan et al., 1997). Flavonols (quercetin and kaempferol) showed higher anti-inflammatory effects than catechins, and the effects of flavonol aglycones have been reported to be higher than those of flavonol glycosides (Rha et al., 2019). A previous study was conducted to screen the phenolic compounds in moringa leaves and evaluate their anti-inflammatory activities using three extracts $(20 \mathrm{mg} / \mathrm{mL})$ of the same species cultivated in different regions and harvested in different periods (Coppin et al., 2013). The quercetin and kaempferol derivatives contents varied, and the inhibitory activity on NO production increased or decreased depending on the plant variety and treatment concentration (20-100 $\mathrm{mg} / \mathrm{mL}$ ); additionally, the anti-inflammatory activities were reported to vary significantly (Coppin et al., 2013).

The phenolics and flavonoid contents, especially catechins and flavonols in the form of aglycones, were higher in the green tea extract than in the moringa leaf extract; these compounds had inhibitory activity on NO production, leading to anti-inflammatory activities. In contrast, the moringa leaf extract seemed to have relatively low concentrations of these compounds for effectively inhibiting NO production.

\section{Antioxidant activity and fatty acid compositions of the protein cubes}

The both TPC and TFC of the protein cubes supplemented with either moringa leaf or green tea powder were in the following order: $7.5 \%$ green tea $>5 \%$ green tea $>7.5 \%$ moringa leaf $>5 \%$ moringa leaf $>$ control $(\mathrm{p}<0.05)$ (Table 1). The FRAP values of the protein cubes were in the following order: $7.5 \%$ green tea $>5 \%$ green tea $>7.5 \%$ moringa leaf $>5 \%$ moringa leaf $>$ control $(p<0.05)$. Among the experimental groups, the DPPH RSC was the lowest in the protein cubes supplemented with 5\% moringa leaf extract (Table 1). The antioxidant activity of the protein cubes supplemented with green tea was higher than that of protein cubes supplemented with moringa leaf extract, owing to the higher phenolic and flavonoid contents of green tea powder. The TPC, TFC, and antioxidant activity of the protein cubes increased as the amount of added powder increased. In line with this, a previous study showed that the antioxidant activity of macaroons supplemented with moringa leaf powder (Baek and Lee, 2020) and cookies (Ahmad et al., 2015) and rice sponge cakes (Lee and Hwang, 2016) supplemented with green tea increased with an increase in the powder content.

The major fatty acids in the protein cubes supplemented with either moringa leaf or green tea powder were the oleic, palmitic, linoleic, stearic, and myristic acids, which accounted for approximately $85 \%$ of the total fatty acids (Table 3 ). The fatty acid compositions of the protein cubes were similar because moringa leaf or green tea powders were added in small amounts (5\% and 7.5\%, respectively), and the lipid contents of the powders were low. On the other hand, the fatty acid composition of the protein cubes seemed to be mostly affected by the fatty acids of the ingredients, such as butter, cream cheese, milk, protein powder, and almond powder.

\section{Physical properties of the protein cubes}

The volumes of the protein cubes supplemented with the powders (except for those supplemented with 5\% green tea), were significantly smaller than those of the control group $(p<0.05)$. The volumes of the protein cubes supplemented with green tea were greater than those of the protein cubes supplemented with moringa leaf extract $(p<0.05)$. Increasing the powder content reduced the protein cube volume $(\mathrm{p}<0.05)$, and the volume of the protein cubes supplemented with $5 \%$ green tea powder was similar to that of the control group ( $p>0.05$ ) (Table 4). The hardness of the protein cubes supplemented with powders was higher than that of the control group, and increasing the powder content led to increased hardness in moringa leaf protein cubes, but decreased hardness in green tea protein cubes $(p<0.05)$. The chewiness and fracturability followed the trend of the hardness (Table 4).

The volume and texture of bakery products are influenced by various factors, including the physicochemical properties of the ingredients and their mixing ratios (Lee and Hwang, 2016). Ingredients with a high water absorption index result 
Table 3. Fatty acid composition of the protein cubes supplemented with moringa leaf or green tea powder

\begin{tabular}{|c|c|c|c|c|c|}
\hline \multirow{2}{*}{$\begin{array}{l}\text { Fatty acid ( } \% \text { of } \\
\text { total fatty acids) }\end{array}$} & \multirow{2}{*}{ Control } & \multicolumn{2}{|c|}{ Moringa leaf } & \multicolumn{2}{|c|}{ Green tea } \\
\hline & & $5 \%$ & $7.5 \%$ & $5 \%$ & $7.5 \%$ \\
\hline $\mathrm{C} 4: 0$ & $0.35 \pm 0.02^{1)}$ & $0.34 \pm 0.03$ & $0.34 \pm 0.05$ & $0.32 \pm 0.01$ & $0.37 \pm 0.02^{\mathrm{NS} 3)}$ \\
\hline C6:0 & $0.55 \pm 0.03^{\mathrm{b} 3)}$ & $0.44 \pm 0.10^{\mathrm{b}}$ & $3.32 \pm 2.57^{\mathrm{a}}$ & $3.95 \pm 1.2^{\mathrm{a}}$ & $1.9 \pm 1.22^{\mathrm{ab}}$ \\
\hline C8:0 & $0.42 \pm 0.03^{\mathrm{ab}}$ & $0.42 \pm 0.04^{\mathrm{ab}}$ & $0.39 \pm 0.02^{\mathrm{b}}$ & $0.39 \pm 0.01^{\mathrm{ab}}$ & $0.43 \pm 0.03^{\mathrm{a}}$ \\
\hline $\mathrm{C} 10: 0$ & $1.28 \pm 0.06$ & $1.28 \pm 0.10$ & $1.22 \pm 0.05$ & $1.22 \pm 0.04$ & $1.31 \pm 0.10^{\mathrm{NS}}$ \\
\hline $\mathrm{C} 12: 0$ & $1.95 \pm 0.05$ & $1.94 \pm 0.13$ & $3.25 \pm 2.68$ & $1.87 \pm 0.03$ & $1.99 \pm 0.04^{\mathrm{NS}}$ \\
\hline $\mathrm{C} 14: 0$ & $6.4 \pm 0.07$ & $6.45 \pm 0.37$ & $6.39 \pm 0.05$ & $6.34 \pm 0.12$ & $6.59 \pm 0.11^{\mathrm{NS}}$ \\
\hline $\mathrm{C} 14: 1$ & $0.48 \pm 0.02$ & $0.46 \pm 0.03$ & $0.45 \pm 0.01$ & $1.36 \pm 1.86^{\mathrm{NS}}$ & $0.49 \pm 0.03$ \\
\hline $\mathrm{C} 15: 0$ & $0.59 \pm 0.01^{\mathrm{b}}$ & $0.6 \pm 0.03^{\mathrm{ab}}$ & $0.59 \pm 0.01^{\mathrm{b}}$ & $0.58 \pm 0.02^{\mathrm{b}}$ & $0.62 \pm 0.01^{\mathrm{a}}$ \\
\hline $\mathrm{C} 16: 0$ & $22.04 \pm 0.06^{\mathrm{b}}$ & $22.48 \pm 1.18^{\mathrm{ab}}$ & $22.25 \pm 0.34^{\mathrm{ab}}$ & $22.51 \pm 0.40^{\mathrm{ab}}$ & $23.13 \pm 0.26^{\mathrm{a}}$ \\
\hline $\mathrm{C} 16: 1$ & $1.23 \pm 0.01$ & $3.74 \pm 4.99^{\mathrm{NS}}$ & $1.19 \pm 0.01$ & $1.17 \pm 0.03$ & $1.22 \pm 0.01$ \\
\hline $\mathrm{C} 17: 0$ & $0.38 \pm 0.01$ & $0.4 \pm 0.03$ & $0.39 \pm 0.00$ & $0.31 \pm 0.18$ & $0.42 \pm 0.02^{\mathrm{NS}}$ \\
\hline $\mathrm{C} 18: 0$ & $7.77 \pm 0.04^{\mathrm{b}}$ & $7.89 \pm 0.38^{\mathrm{ab}}$ & $7.88 \pm 0.18^{\mathrm{ab}}$ & $8.01 \pm 0.15^{\mathrm{ab}}$ & $8.19 \pm 0.08^{\mathrm{a}}$ \\
\hline C18:1t & $1.25 \pm 0.07$ & $1.24 \pm 0.07$ & $1.22 \pm 0.03$ & $1.23 \pm 0.02$ & $1.28 \pm 0.01^{\mathrm{NS}}$ \\
\hline $\mathrm{C} 18: 1 \mathrm{n}-9 \mathrm{c}$ & $41.85 \pm 0.24^{\mathrm{a}}$ & $39.9 \pm 1.88^{\mathrm{b}}$ & $38.75 \pm 1.01^{\mathrm{b}}$ & $39.17 \pm 1.17^{\mathrm{b}}$ & $39.99 \pm 0.57^{\mathrm{b}}$ \\
\hline $\mathrm{C} 18: 1 \mathrm{n}-7 \mathrm{c}$ & $0.78 \pm 0.03^{\mathrm{a}}$ & $0.74 \pm 0.04^{\mathrm{ab}}$ & $0.72 \pm 0.01^{\mathrm{ab}}$ & $0.59 \pm 0.24^{\mathrm{b}}$ & $0.74 \pm 0.01^{\mathrm{ab}}$ \\
\hline $\mathrm{C} 18: 2 \mathrm{n}-6 \mathrm{c}$ & $11.6 \pm 0.06^{\mathrm{a}}$ & $10.43 \pm 0.50^{\mathrm{b}}$ & $10.24 \pm 0.28^{\mathrm{bc}}$ & $9.76 \pm 0.20^{c}$ & $10.11 \pm 0.15^{\mathrm{bc}}$ \\
\hline $\mathrm{C} 20: 0$ & $0.14 \pm 0.00^{\mathrm{NS}}$ & $0.13 \pm 0.01$ & $0.13 \pm 0.00$ & $0.13 \pm 0.00$ & $0.14 \pm 0.00$ \\
\hline C18:3n-3 & $0.19 \pm 0.02$ & $0.2 \pm 0.01$ & $0.27 \pm 0.12^{\mathrm{NS}}$ & $0.21 \pm 0.01$ & $0.23 \pm 0.01$ \\
\hline $\mathrm{C} 21: 0$ & $0.27 \pm 0.02$ & $0.3 \pm 0.03$ & $0.24 \pm 0.11$ & $0.32 \pm 0.01^{\mathrm{NS}}$ & $0.31 \pm 0.01$ \\
\hline $\mathrm{C} 20: 2$ & $0.04 \pm 0.03^{\mathrm{c}}$ & $0.11 \pm 0.02^{\mathrm{bc}}$ & $0.3 \pm 0.18^{\mathrm{a}}$ & $0.2 \pm 0.01^{\mathrm{ab}}$ & $0.16 \pm 0.02^{\mathrm{abc}}$ \\
\hline $\mathrm{SFA}^{4)}$ & $42.29 \pm 0.44^{\mathrm{b}}$ & $42.88 \pm 2.57^{b}$ & $46.53 \pm 6.07^{\mathrm{a}}$ & $46.07 \pm 2.19^{\mathrm{a}}$ & $45.55 \pm 1.94^{\mathrm{a}}$ \\
\hline $\mathrm{USFA}^{4)}$ & $57.7 \pm 0.54^{\mathrm{a}}$ & $57.08 \pm 7.57^{\mathrm{a}}$ & $53.45 \pm 1.74^{\mathrm{b}}$ & $53.92 \pm 3.54^{\mathrm{b}}$ & $54.44 \pm 0.84^{\mathrm{b}}$ \\
\hline MUFA $^{4)}$ & $45.67 \pm 0.38^{\mathrm{a}}$ & $46.17 \pm 7.02^{\mathrm{a}}$ & $42.42 \pm 1.07^{\mathrm{b}}$ & $43.59 \pm 3.32^{\mathrm{ab}}$ & $43.78 \pm 0.63^{\mathrm{ab}}$ \\
\hline PUFA $^{4)}$ & $12.03 \pm 0.16^{\mathrm{a}}$ & $10.91 \pm 0.55^{\mathrm{b}}$ & $11.03 \pm 0.67^{b}$ & $10.33 \pm 0.22^{\mathrm{c}}$ & $10.66 \pm 0.21^{\mathrm{bc}}$ \\
\hline
\end{tabular}

${ }^{1)}$ Each value is mean $\pm \mathrm{SD}(\mathrm{n}=4)$

${ }^{2)}$ Values with different superscripts within the same row are significantly different by Duncan's multiple range test at $\mathrm{p}<0.05$.

${ }^{3)}$ Not significantly different at $\mathrm{p}<0.05$.

${ }^{4)}$ SFA, saturated fatty acid; USFA, unsaturated fatty acid; MUFA, monounsaturated fatty acid; PUFA, polyunsaturated fatty acid.

in strong water binding during kneading, and cause a reduction in the free water content needed for dough swelling, leading to decreased volume and increased hardness (Ahmad et al., 2015; Lee and Hwang, 2016; Šarić et al., 2018). The use of ingredients with higher protein content can increase water absorption and the formation of an excessively structured gluten network, thereby decreasing the spread and thickness of the bakery product (Dachana et al., 2010). A high dietary fiber content may increase the water content in the dough, causing the dilution of the gluten network and decreasing the hardness and volume of bakery products (Ahmad et al., 2015; Lee and Hwang, 2016).

The protein content in moringa leaves is in the 28.9-30.29\% range (Melesse, 2011; Moyo et al., 2011), and is higher than those in green tea (15\%) (Cabrera et al., 
Table 4. Volumes, textures and sensory evaluations of the protein cubes supplemented with moringa leaf or green tea powder

\begin{tabular}{|c|c|c|c|c|c|}
\hline & \multirow{2}{*}{ Control } & \multicolumn{2}{|c|}{ Moringa leaf } & \multicolumn{2}{|c|}{ Green tea } \\
\hline & & $5 \%$ & $7.5 \%$ & $5 \%$ & $7.5 \%$ \\
\hline \multicolumn{6}{|c|}{ Volume and texture properties } \\
\hline Volume (mL) & $10.00 \pm 0.00^{1) \mathrm{a} 2)}$ & $9.29 \pm 0.00^{\mathrm{b}}$ & $8.57 \pm 0.00^{\mathrm{c}}$ & $10.00 \pm 0.00^{\mathrm{a} 0}$ & $9.46 \pm 0.25^{\mathrm{b}}$ \\
\hline Chewiness (g) & $130.29 \pm 9.77^{\mathrm{d}}$ & $174.88 \pm 40.89^{c}$ & $407.94 \pm 13.03^{\mathrm{a}}$ & $221.74 \pm 13.70^{\mathrm{b}}$ & $163.53 \pm 4.00^{\mathrm{c}}$ \\
\hline Fracturability (g) & $5,316.09 \pm 253.19^{d}$ & $7,174.58 \pm 1510.65^{\mathrm{c}}$ & $12,899.97 \pm 934.75^{\mathrm{a}}$ & $8,652.72 \pm 0.71^{\mathrm{b}}$ & $6,431.51 \pm 82.28^{\mathrm{d}}$ \\
\hline Hardness $\left(\mathrm{g} / \mathrm{cm}^{2}\right)$ & $12,146.11 \pm 461.32^{\mathrm{d}}$ & $16,442.89 \pm 2,532.36^{\mathrm{c}}$ & $45,989.12 \pm 1,016.87^{\mathrm{a}}$ & $21,428.28 \pm 2,279.89^{\mathrm{b}}$ & $15,608.02 \pm 670.96^{\mathrm{c}}$ \\
\hline \multicolumn{6}{|l|}{ Sensory attribute intensity } \\
\hline Greenish color & $1.02 \pm 0.15^{\mathrm{d} 2)}$ & $3.90 \pm 0.76^{\mathrm{c}}$ & $5.26 \pm 0.91^{\mathrm{b}}$ & $5.12 \pm 0.99^{\mathrm{b}}$ & $6.43 \pm 0.86^{\mathrm{a}}$ \\
\hline Grassy smell & $1.17 \pm 0.44^{\mathrm{c}}$ & $4.50 \pm 1.33^{\mathrm{b}}$ & $5.00 \pm 1.29^{\mathrm{b}}$ & $4.50 \pm 1.42^{\mathrm{b}}$ & $5.57 \pm 1.21^{\mathrm{a}}$ \\
\hline Grassy taste & $1.26 \pm 0.63^{\mathrm{d}}$ & $4.76 \pm 1.41^{\mathrm{bc}}$ & $5.02 \pm 1.26^{\mathrm{b}}$ & $4.48 \pm 1.19^{\mathrm{c}}$ & $5.67 \pm 1.26^{\mathrm{a}}$ \\
\hline Hardness & $4.00 \pm 1.29^{\mathrm{c}}$ & $4.70 \pm 0.93^{\mathrm{ab}}$ & $4.58 \pm 1.07^{\mathrm{b}}$ & $4.98 \pm 1.26^{\mathrm{ab}}$ & $5.19 \pm 1.23^{\mathrm{a}}$ \\
\hline \multicolumn{6}{|l|}{ Sensory acceptability } \\
\hline Appearance & $4.71 \pm 1.52^{\mathrm{ab} 2)}$ & $4.93 \pm 1.20^{\mathrm{a}}$ & $5.33 \pm 1.20^{\mathrm{a}}$ & $4.29 \pm 1.24^{\mathrm{b}}$ & $4.83 \pm 1.62^{\mathrm{ab}}$ \\
\hline Color & $4.26 \pm 1.74^{\mathrm{b}}$ & $5.05 \pm 1.23^{\mathrm{a}}$ & $5.38 \pm 1.23^{\mathrm{a}}$ & $3.79 \pm 1.28^{\mathrm{b}}$ & $4.31 \pm 1.55^{\mathrm{b}}$ \\
\hline Aroma & $4.50 \pm 1.38^{\mathrm{a}}$ & $4.12 \pm 1.29^{\mathrm{a}}$ & $3.98 \pm 1.37^{\mathrm{a}}$ & $4.57 \pm 1.35^{\mathrm{a}}$ & $4.60 \pm 1.52^{\mathrm{a}}$ \\
\hline Taste & $4.24 \pm 1.53^{\mathrm{a}}$ & $4.17 \pm 1.62^{\mathrm{a}}$ & $3.95 \pm 1.51^{\mathrm{a}}$ & $4.40 \pm 1.48^{\mathrm{a}}$ & $4.14 \pm 1.66^{\mathrm{a}}$ \\
\hline Texture & $4.52 \pm 1.29^{\mathrm{a}}$ & $4.21 \pm 1.20^{\mathrm{a}}$ & $4.19 \pm 1.25^{\mathrm{a}}$ & $4.62 \pm 1.27^{\mathrm{a}}$ & $4.17 \pm 1.38^{\mathrm{a}}$ \\
\hline Overall acceptability & $4.62 \pm 1.41^{\mathrm{a}}$ & $4.71 \pm 1.35^{\mathrm{a}}$ & $4.12 \pm 1.25^{\mathrm{a}}$ & $4.64 \pm 1.34^{\mathrm{a}}$ & $4.43 \pm 1.35^{\mathrm{a}}$ \\
\hline
\end{tabular}

${ }^{1)}$ Each values are expressed as mean $\pm \mathrm{SD}(\mathrm{n}=42)$ using 7-point hedonic scale (1=extremely weak or dislike, 4=normal, 7=extremely strong or like).

${ }^{2)}$ Values with different superscripts within the same row are significantly different by Duncan's multiple range test at $\mathrm{p}<0.05$.

2006) and wheat flour (10.4\%) (Dachana et al., 2010). The water absorption index of moringa leaves (3.21) is higher than that of green tea (1.79) (Baek and Lee, 2020), while the fiber content is higher in green tea $(26 \%)$ than in moringa leaves (8.51\%) (Cabrera et al., 2006; Melesse, 2011). In the preparation of protein cubes, increasing the moringa leaf powder content leads to increasing protein content; additionally, the increased water absorption reduces the volume but increases the hardness of the protein cubes. In contrast, increasing the green tea powder content, which is high in dietary fiber, likely reduces the volume and hardness of the protein cubes. Recent studies have reported that increased contents of moringa leaf powder with high protein content increased the hardness of cookies (Dachana et al., 2010), while the high dietary fiber content in green tea has been reported to reduce the hardness of cookies (Ahmad et al., 2015). These reports corroborate the results of the present study.

Chewiness, which refers to the number of chews required for a food to be swallowed, and fracturability, which is the ability to break a cookie into pieces using the incisors, are positively correlated with hardness (Paula and Conti-Silva, 2014). In the present study, the chewiness and fracturability of the protein cubes tended to be similar to hardness, which are consistent with results of a the previous study (Paula and Conti-Silva, 2014).

\section{Sensory evaluation of the protein cubes}

The photographs and sensory attribute intensity and acceptability of the protein cubes supplemented with either the moringa leaf or green tea powders are presented in Fig. 2 and Table 4. The intensities of grassy smell and taste in the protein cubes increased as the powder content increased, and were higher in the green tea protein cubes than in the 


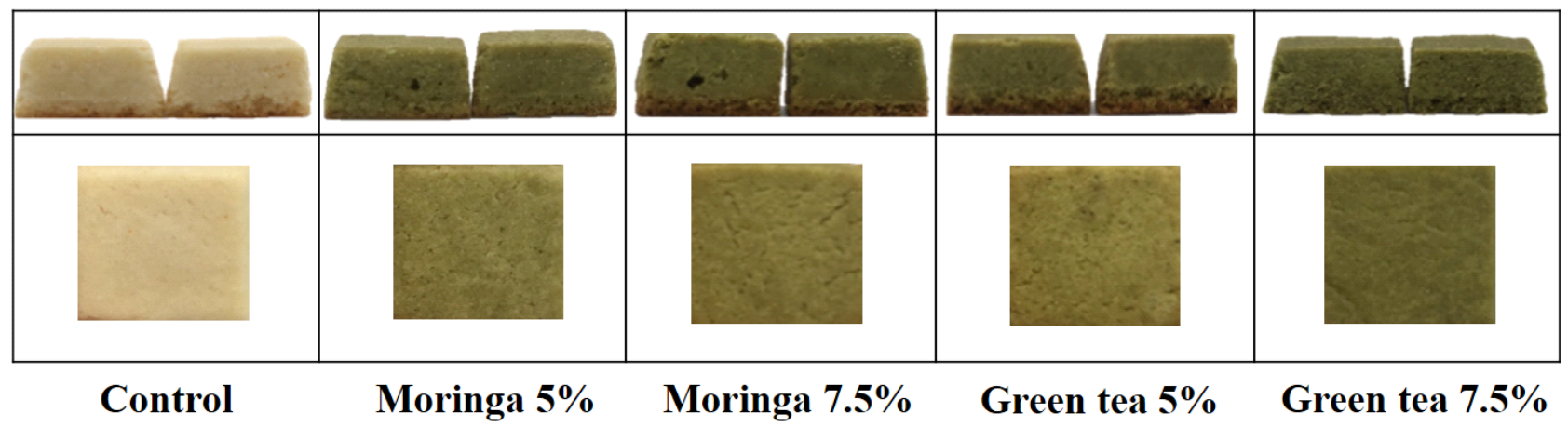

Fig. 2. Photographs of the protein cubes supplemented with moringa leaf or green tea powder.

moringa leaf protein cubes. The greenish color of the green tea protein cubes was significantly more intense than that of the moringa leaf protein cubes $(p<0.05)$, which could be attributed to the chlorophyll content that is higher in green tea than in moringa leaves. The hardness was higher in the protein cubes supplemented with the powders than in the control group $(p<0.05)$; the green tea powder protein cubes were harder than the moringa leaf powder protein cubes.

The sensory acceptabilities of appearance and color were significantly higher in moringa leaf protein cubes $(p<0.05)$ than in green tea protein cubes, while the acceptabilities of aroma, taste, and texture were higher in green tea protein cubes than in moringa leaf protein cubes, but were not significantly different $(\mathrm{p}>0.05)$. Compared with moringa leaf powder, the greenness of green tea powder had a negative effect on the acceptability of appearance and color of the protein cubes. The strong grassy smell and taste appeared to have positive effects on the acceptability of the aroma and taste of the protein cubes. The sensory acceptability of appearance and color was higher in protein cubes with 7.5\% powder content, and the acceptability of the aroma, texture, and taste was higher in protein cubes with $5 \%$ powder content. The overall acceptability did not differ significantly among the protein cubes ( $p>0.05$ ), although it was higher for protein cubes with $5 \%$ powder content than for those with $7.5 \%$ powder content. The protein cubes containing 5\% moringa leaf powder had the highest overall acceptability.

The present study revealed that green tea powder not only had good antioxidant and anti-inflammatory properties, but also a higher EFA content than moringa leaf powder. Supplementing the protein cubes with either moringa leaf or green tea powder affected positively the cubes' appearance and color, as compared to the control. Further studies are needed to assess NO production by using varying concentrations of moringa leaf extract, as the concentration level of moringa leaf extract in the present study was not enough to exert an inhibitory effect on NO production. In conclusion, both powders could be used as functional food additives for high-protein and nutrient-rich bakery products. The green tea powder was more suitable than moringa leaf powder for the development of functional foods with high consumer acceptability and antioxidant and anti-inflammatory properties.

\section{Acknowledgments}

This research was supported by the Daegu University, 2019

\section{Conflict of interests}

The authors declare no potential conflict of interest.

\section{ORICD}

Chae-Wan Baek https://orcid.org/0000-0001-6810-2570

Jeung-Hee Lee https://orcid.org/0000-0002-4224-771X

\section{References}

Dachana KB, Rajiv J, Indrani D, Prakash J. Effect of dried moringa (Moringa oleifera Lam) leaves on rheological, microstructural, nutritional, textural and organoleptic characteristics of cookies. J Food Qual, 33, 660-667 (2010) 
Ahmad M, Baba WN, Wani TA, Gani A, Gani A, Shah U, Wani SM, Masoodi FA. Effect of green tea powder on thermal, rheological \& functional properties of wheat fl our and physical, nutraceutical \& sensory analysis of cookies. J Food Sci Technol, 52, $5799-5807$ (2015)

Anh NTL, Tuan HQ, Tu NTM. Variations in fatty acid composition of tea leaves (Camella sinensis) due to plucking time and cultivars. Vietnam J Sci Technol, 54, 284-290 (2016)

AT food information statistics system. https://www.atfis.or.kr/ article/M001050000/view.do?articleId=3093 (accessed May 2021)

Baek CW, Lee JH. Quality evaluation of macaroons added with moringa leaf (Moringa oleifera Lam.) and green tea powder. Korean J Food Preserv, 27, 555-565 (2020)

Cabrera C, Artacho R, Gimenez R. Beneficial effects of green tea-a review. J Am Coll Nutr, 25, $79-99$ (2006)

Chan MMY, Fong D, Ho CT, Huang HI. Inhibition of inducible nitric oxide synthase gene expression and enzyme activity by epigallocatechin gallate, a natural product from green tea. Biochem Pharmacol, 54, 12811286 (1997)

Chang HJ, Kim YH, Kang YH, Choi MH, Lee JH. Antioxidant and antibacterial effects of medicinal plants and their stick-type medicinal concentrated beverages. Food Sci Biotechnol, 29, 1413-1243 (2020)

Chen H, Ho CT. Comparative study on total polyphenol content and total antioxidant activity of tea (Camellia sinensis). In: Antioxidant Measurement and Applications, American Chemical Society, Washington DC, USA, p 195-214 (2007)

Choe EO, Lee HG, Park KH, Lee SH. Factors affecting the components of chlorophyll pigment in spinach during storage. J Appl Biol Chem, 44, 73-80 (2001)

Coppin JP, Xu Y, Chen H, Pan MH, Ho CT, Juliani R, Simon JE, $\mathrm{Wu}$ Q. Determination of flavonoids by LC/MS and anti-inflammatory activity in Moringa oleifera. J Funct Foods, 5, 1892-1899 (2013)

Cribb PJ, Hayes A. Effects of supplement-timing and resistance exercise on skeletal muscle hypertrophy. Med Sci Sports Exercise, 38, 1918-1925 (2006)

Das UN. Essential fatty acids: biochemistry, physiology and pathology. Biotechnol J, 1, 420-439 (2006)

Gan LJ, Yang D, Shin JA, Kim SJ, Hong ST, Lee JH, Sung
CK, Lee KT. Oxidative comparison of emulsion systems from fish oil-based structured lipid versus physically blended lipid with purple-fleshed sweet potato (Ipomoea batatas L.) extracts. J Agric Food Chem, 60, 467-475 (2012)

Kripanand SM, Guruguntla S, Korra S. Effect of various drying methods on quality and flavor characteristics of mint leaves (Mentha spicata L.). J Food Pharm Sci, 3, 38-45 (2015)

Lee LS, Park JD, Cha HS, Lee YM, Park JW, Kim SH. Physicochemical properties of powdered green tea in korea. Korean J Food Sci Technol, 42, 33-38 (2010)

Lee MJ, Hwang ES. Quality characteristics and antioxidant activity of rice sponge cake with added green tea powder. Korean J Food Sci Technol, 48, 354-360 (2016)

Lim SW, Jeon WJ, Park HK. Body images of male university students using fitness centers and their experience on protein supplement intake. Korean J Phys Educ, 55, 521-534 (2016)

Melesse A. Comparative assessment on chemical compositions and feeding values of leaves of Moringa stenopetala and Moringa oleifera using in vitro gas production method. Ethiop J Appl Sci Technol, 2, 29-38 (2011)

Moyo B, Masika PJ, Hugo A, Muchenje V. Nutritional characterization of Moringa (Moringa oleifera Lam.) leaves. Afr J Biotechnol, 10, 12925-12933 (2011)

Nadiah NI, Cheng LH, Azhar ME, Karim AA, Uthumporn U, Ruri AS. Determination of phenolics and antioxidant properties in tea and the effects of polyphenols on alpha-amylase activity. Pak J Nutr, 14, 808-817 (2015)

Omodanisi EI, Aboua YG, Oguntibeju OO. Assessment of the anti-hyperglycaemic, anti-inflammatory and antioxidant activities of the methanol extract of Moringa oleifera in diabetes-induced nephrotoxic male wistar rats. Molecules, 22, 439 (2017)

Park HJ, Oh HI, Yang JY, Oh JE, Kang NE, Cho MS. A study on the consumer's preference and purchasing behavior of high-protein bars with soy protein isolate. $\mathrm{J}$ Korean Soc Food Sci Nutr, 49, 270-278 (2020)

Paula AM, Conti-Silva AC. Texture profile and correlation between sensory and instrumental analyses on extruded snacks. J Food Eng, 121, 9-14 (2014)

Re R, Pellegrini N, Proteggente A, Pannala A, Yang M, Rice-Evans C. Antioxidant activity applying an improved 
ABTS radical cation decolorization assay. Free Radic

Biol Med, 26, 1231-1237 (1999)

Rha CS, Jeong HW, Park SB, Lee SY, Jung YS, Kim DO. Antioxidative, anti-inflammatory, and anticancer effects of purified flavonol glycosides and aglycones in green tea. Antioxidants, 8, 278 (2019)

Rodriguez-Perez C, Quirantes-Pine R, Fernandez-Gutierrez A, Segura-Carretero A. Optimization of extraction method to obtain a phenolic compounds-rich extract from Moringa oleifera Lam. leaves. Ind Crop Prod, 66, 246-254 (2015)

Santangelo C, Vari R, Scazzocchio B, Di Benedetto R, Filesi C, Masella R. Polyphenols, intracellular signalling and inflammation. Ann Ist Super Sanita, 43, 394-405 (2007)

Saric B, Dapcevic-Hadnadev T, Hadnadev M, Sakac M, Mandic A, Misan A, Skrobot D. Fiber concentrates from raspberry and blueberry pomace in gluten-free cookie formulation: Effect on dough rheology and cookie baking properties. J Texture Stud, 50, 124-130 (2019)

Siddhuraju R, Becker K. Antioxidant properties of various solvent extracts of total phenolic constituents from three different agroclimatic origins of drumstick tree (Moringa oleifera Lam.) leaves. J Agric Food Chem, 51, 21442155 (2003)
Sreelatha S, Padma PR. Antioxidant activity and total phenolic content of Moringa oleifera leaves in two stages of maturity. Plant Foods Hum Nutr, 64, 303-311 (2009)

Stewart AJ, Mullen W, Crozier A. On-line high-performance liquid chromatography analysis of the antioxidant activity of phenolic compounds in green and black tea. Mol Nutr Food Res, 49, 52-60 (2005)

Teres S, Barcelo-Coblijn G, Benet M, Alvarez R, Bressani $\mathrm{R}$, Halver JE, Escriba PV. Oleic acid content is responsible for the reduction in blood pressure induced by olive oil. Proc Natl Acad Sci USA, 105, 1381113816 (2008)

Wasonowati C, Sulistyaningsih E, Indradewa D, Kurniasih B. Physiological characters of Moringa oleifera Lamk in madura. AIP Conf Proc, 2120, 030024-1-030024-6 (2019)

Yang LG, Song ZX, Yin H, Wang YY, Shu GF, Lu HX, Wang SK, Sun GJ. Low n-6/n-3 pufa ratio improves lipid metabolism, inflammation, oxidative stress and endothelial function in rats using plant oils as n-3 fatty acid source. Lipids, 51, 49-59 (2016) 